\title{
ASEAN Single Market: Revisiting Rules and Strategies on the Enforcement of Free Flow of Goods in ASEAN
}

\author{
Riyad Febrian Anwar \\ Undergraduate Program, Faculty of Law, Hasanuddin University \\ Jln. Perintis Kemerdekaan Km. 10, Tamalanrea, Makassar, South Sulawesi, 90245, Indonesia. \\ Tel.: +62-81219052773 E-mail: riyadanwar@gmail.com
}

Submitted: Jul 13, 2015; Reviewed: Jul 27, 2015; Accepted: Aug 8, 2015

\begin{abstract}
Whether we are ready or not, people in Indonesia and the rest of Southeastern Asia will soon welcome the ASEAN Economic Communities (AEC) by the end 2015. Therefore, there are needs to evaluate the progress in ASEAN rules and strategies thus far. By employing normative study, this paper finds and further recommends the following: Firstly, ASEAN almost reached its peak points in eliminating the tariff barriers, yet to come are the elimination on 'sensitive' and 'highly sensitive list' tariffs on imported agriculture commodities; Secondly, Non-Tariff Barriers (NTB) remain to be one of the major problems in intra-ASEAN trades; Thirdly, Member States reluctances to invoke the ASEAN dispute settlement mechanism for their trading disputes may potentially hinder the effectiveness of AEC in the future; and Finally, the protection of intellectual property remains low in the region as the ASEAN Intellectual Property Rights (IPR) Action plan 2011-2015 is still deemed ineffective to reforms the IP regulations within Member States.
\end{abstract}

Keywords: ASEAN; ASEAN Economic Community; Free Flow of Goods; Single Market

\section{INTRODUCTION}

The idea of evolving ASEAN into a more integrated economic community could be traced way back in 2002. Back in November 2002, the ASEAN Heads of Government proposed that the region should consider the possibility of creating an 'ASEAN Economic Community' (AEC) by 2020, with even more recent proposals to move up the date to $2015 .^{1}$

1 Michael Oborne. "International Economic Integration and Asia" in Organisation for Economic Co-operation and Development (OECD). (2005).
The reasons behind the decision to create the AEC are many, including: a) The desire to create a post-AFTA agenda that would be comprehensive; b) The perceived need to deepen economic integration in ASEAN in light of the new international commercial environment, especially the dominance of FTAs; c) The possibility that bilateral FTAs could actually jeopardize ASEAN integration since all Member Countries were free to

Regional Integration in the Asia Pacific: Issues and Prospects. Paris: OECD, p. 4 
pursue their own commercial-policy agenda; and d) The recognition since the Asian Crisis that cooperation in the real and financial sectors must be extended concomitantly, and that free flows of skilled labor will be necessary to do this. ${ }^{2}$

The ASEAN Economic Community (AEC) is an ambitious effort at deep market integration, characterized by the free flow of goods, services and investment, a freer flow of financial capital, enhanced connectivity, and expanded opportunities for intra-regional labor migration. It can be seen as a significant step in the region's post-1997 reorientation - away from traditional economic partners, such as Japan, the United States and the European Union, and towards the region itself, as well as to emerging markets such as China and India. ${ }^{3}$

The current design of ASEAN regional economic cooperation has also been shaped by more recent global economic shocks, such as the collapse of the United States subprime mortgage market and the euro zone debt crisis. While ASEAN economies have weathered these storms, many of the world's leading industrialized countries are struggling to shake off the effects of recession. ${ }^{4}$

According to Plummer, the free flow of all labor, including unskilled labor, was deemed too politically difficultto consider in the AEC. See Michael G. Plummer and Erik Jones. (2006). International Economic Integration and Asia: Advanced Research in Asian Economic Studies. Vol. 3. Singapore: World Scientific, p. 5

3 Asian Development Bank. (2014).ASEAN Community 2015: Managing integration for better jobs and shared prosperity. Thailand: International Labour Organization and Asian Development Bank, p. 2

4 Asian Development Bank. (2014)., Ibid
One AEC pillars are the creation of single market and production base ${ }^{5}$ where the single market will be expected to provide an integrated market with reduced barriers to trade and investment. Investors can move more freely in the region and have greater access to capital and benefit from moving goods easily across borders. ${ }^{6}$ AEC also provides that the single market and production base pillar will comprise five core elements: the free flow of goods, services and investment, a freer flow of capital and the free flow of skilled labor. ${ }^{7}$

ASEAN's economic performance towards ASEAN single market has been remarkable. In 2013, ASEAN's gross domestic product (GDP) stood at \$2.4 trillion, accounting for 3.3 per cent of the world's economy. During the period 200713, ASEAN economies, with the exception of Brunei Darussalam, grew faster than the global average, proving relatively resilient to successive international crises in the late2000s. In 2013, GDP growth for the world as a whole was 3.0 per cent, where ASEAN showed distinct trend by standing on 4.9 per cent. ${ }^{8}$

The numbers alone would not be enough to determine ASEAN readiness on the free flow of goods era. This paper will address some vital rules on ASEAN's free flow of goods and discuss how well the implementation of those rules.

\footnotetext{
ASEAN. ASEAN Economic Community Blueprint (AEC Blueprint). 2007, Action Plan 6 ASEAN.AEC Blueprint, Action Plan 6

7 ASEAN.AEC Blueprint, Action Plan 9

8 IMF.World Economic Outlook Database. April 2014. As cited in Asian Development Bank. (2014)., Op.Cit., p. 2 - 5
} 


\section{METHODS}

This paper mainly employs library based research or pure theoretical research, where the research concerned with analysis of the legal doctrine and how it has been developed and applied which consists of either simple research directed at finding a specific statement of the law or a more complex and in depth analysis of legal reasoning, ${ }^{9}$ by reading through legal literatures, treatises, magazines, newspapers, essay and research report relevant to the concerned problems.

The following paper divided its sources into 3 (three) criteria, that is: 1) Primary law materials (consists of international treaties and regulations relevant to the Thesis concerned); 2) Secondary law materials (consists treatises and other academic publication relevant to the issue concerned) and; 3 ) Tertiary law materials (consists of dictionary and translation tools to help deciphering the foreign sources)

Data obtained will be selected through validation procedure in effort to test data reliability as written reference for this publication. Any valid data would subsequently be classified based on substance and its hierarchy as international treaties, judicial decisions and doctrines. The data would then be analysed using inductive and deductive methods. These methods commonly derived in scientific analysis of international law. ${ }^{10}$

9 Ashish Kumar Singhal. (2012). Doctrinal and Socio-Legal Methods of Research: Merits and Demerits. Educational Research Journal. Vol. 2(7). July 2012, p. 252. Available from: http://www. resjournals.com/ERJ. [Accessed 17/11/2014].

10 Christian Dominice. Methodology of International Law,p. 339, as cited in Rudolf Dolzer et.al. (1984). Encyclopedia of Public International Law.Vol. 7. the Netherlands: North-Holland, pg. 334-339

\section{ANALYSIS AND DISCUSSION}

ASEAN Rules on Free Flow of Goods

A series of trade agreements have been concluded by ASEAN such as the 1977 Agreement on ASEAN Preferential Trading Arrangements, the 1992 Framework Agreement on Enhancing ASEAN Economic Cooperation, and the 1992 Agreement on the Common Effective Preferential Tariff Scheme for the ASEAN Free Trade Area [CEPT-AFTA].

Those economic agreements, however, were too broad and less enforceable as multilateral instruments in order to accommodate the need for rule of law within intra-ASEAN market. Subsequently in August 2007, the ASEAN Economic Minister agreed to enhance the CEPT-AFTA into a more comprehensive legal instrument. This led to the signing of the ASEAN Trade in Goods Agreement [ATIGA] in February 2009 which later entered into force on May 2010. By the entry of this Treaty, all Member States had undergone ratification for this Treaty, subjecting all commercial policies in ASEAN on import and export to be compatible with the Treaty.

\section{Elimination of Tariff Barriers}

One of the distinct rules on ASEAN free flow of goods regarding the reduction or elimination of import duties could be found in Article 19(1) of the ATIGA, which held that:

Except as otherwise provided in this Agreement, Member States shall eliminate import duties on all products traded between the Member States by 2010 for ASEAN-6 and by 2015, with flexibility to 2018, for CLMV. 
Article 19(1) ATIGA enshrines not only the obligation to remove custom duties but also time limit in achieving it for Member States. ATIGA divided ASEAN countries in two major groups: 1) The ASEAN-6 (Brunei, Indonesia, Malaysia, Philippines, Singapore, and Thailand), where it has duty to fully eliminate import duties by the end of 2015; and 2) The CLMV (Cambodia, Laos, Myanmar and Viet Nam), where the time limit is rather loosen up that is by the end of $2018 .^{11}$

Notwithstanding to Article 19(1) ATIGA, the subsequent paragraph on the Article gives Member States discretion to decide either to 'eliminate' or to 'reduce' the import duties on originating goods of other Member States. ${ }^{12}$ When Member States decided to reduce the duties instead of eliminating it, the duties should be lowered to the minimum percentage allowed by the Treaty (Commonly no higher than 5\%).

In addition, for goods which receive the benefits of free flow of goods. They have to 'originate' from any of ASEAN Member States. ATIGA adopted CEPT's Rule of Origin where "a product shall be deemed to

11 The rationale behind this division is because when the AFTA agreement was originally signed, ASEAN had only six members (Brunei, Indonesia, Malaysia, the Philippines, Singapore, and Thailand). Vietnam later joined in 1995, Laos and Burma in 1997, and Cambodia in 1999. When the CLMV joined ASEAN, the countries have not fully met AFTA's obligations, but they are officially considered part of the AFTA as they were required to sign the agreement upon entry into ASEAN. Therefore, they were given longer time frames in which to meet AFTA's tariff reduction obligations. See Asian Economic Institute. (2015). Trade Organizations: ASEAN. Available from: http://www. asiaecon.org/trade_relations/get_to_item/4. [Accessed 27 June 2015]

12 ASEAN. ASEAN Trade in Goods Agreement (ATIGA). 2010, Art. 19(2) be originating from ASEAN Member States, if at least $40 \%$ of its content originates from any Member State". ${ }^{13}$ Based on that threshold, Article 28(1)(a) ATIGA provides that:

Goods shall be deemed to be originating in the Member State where working or processing of the goods has taken place... if the goods have regional value content (hereinafter referred to as "ASEAN Value Content" or the "Regional Value Content [RVC]") of not less than forty percent (40\%).

To practically determine whether the goods are 'ASEAN-originated', ATIGA set out a formula which can be found in Article 29 to calculate the goods' RVC. In addition, we should aware that some trans-border charges are exempted from custom duties, those are:

a) Charge equivalent to an internal tax impose consistently with the provision of Article III(2) GATT, in respect of the like domestic goods or in respect of goods from which the imported goods have been manufactured or produced in whole in part; ${ }^{14}$

b) Anti-dumping or countervailing duty applied consistent with the provisions of Article VI GATT, the Agreement on Implementation of Article VI of GATT 1994, and the Agreement on Subsidies and Countervailing Measures in Annex 1A to the World Trade Organization [WTO] Agreement; ${ }^{15}$ or

c) Fee or any charge commensurate with

13 ASEAN. Agreement on the Common Effective Preferential Tariff Scheme for the ASEAN Free Trade Area (CEPT-AFTA). 1992, Art. 2(4)

14 ASEAN. ATIGA, Art. 1(c)(ii)

15 ASEAN. ATIGA, Art. 1(c)(ii) 
the cost of services rendered. ${ }^{16}$

Since the creation of AFTA until the very day ATIGA was enforced, ASEAN efforts to remove tariff barriers have been significant, whereby in 2010, duties were eliminated on $99.2 \%$ of tariff lines for the ASEAN-6 Member States; in the remaining Member States, $97.52 \%$ of tariff lines have been reduced to $0-5$ percent. ${ }^{17}$

Having said that, the next round for this tariff reforms shall be challenging, as the rests of tariff elimination would then address 'sensitive list' and 'highly sensitive list' goods. The sensitive list and highly sensitive list are country specific list of unprocessed agricultural products which are offered a longer time for the implementation of tariff elimination. This delay is mainly because ideas to cut down regional barriers to trade in agricultural commodities are very sensitive politically and socially. ${ }^{18}$ Tariff elimination on sensitive and highly sensitive goods would economically affect the agriculture based countries in ASEAN - particularly for poverty reduction in the region, as the main parties affected by agricultural integration will be the poor farmers and urban workers. ${ }^{19}$

\section{Elimination of Non-Tariff Barriers}

Apart from eliminating tariff barriers, single market and production base by $\mathrm{AEC}$ require more than mere elimination on import tariffs since NTBs had emerged as a serious trade impediment in ASEAN. ${ }^{20}$ Elimination of

16 ASEAN. ATIGA, Art. 1(c)(iii); See also ASEAN. ATIGA, Art. 7(1)

17 ASEAN. (2014). Thinking Globally, Prospering Regionally: ASEAN Economic Community 2015. Jakarta, Indonesia: ASEAN, p. 4

18 See OECD. (2005). Op.Cit., p. 15

19 See OECD. (2005). Ibid

20 Siow Yue Chia. (2013). The ASEAN Economic
NTBs such as safety and conformance rules, difference on custom inspection procedures, transit goods transportation mechanisms and rules of origin undoubtedly constitutes biggest obstacles in reaching AEC. More recently, we could observe few non-tariff barriers coming from Indonesia, Thailand, and the Philippines such as government prohibition in the use of major ports in Jakarta, and different import standards for poultry trade between Thailand and Philippines. ${ }^{21}$

Pursuant to ATIGA, non-tariff barriers [NTB] means "measures other than tariffs which effectively prohibit or restrict imports or exports of goods within Member States". ${ }^{22}$ Unless it is allowed by their rights and obligation under WTO and other exceptions contained within ATIGA, Member States are prohibited to adopt any measure equivalent NTB. ${ }^{23}$ More specifically, ATIGA forbids any measures with effect of $\mathrm{QR},{ }^{24}$ a measure intended to prohibit or restrict quantity of trade with other Member States, whether through quotas, licences or other measures with equivalent effect, including administrative measures and requirements which restrict trade. ${ }^{25}$

There is no pre-defined list on what measures would constitute NTB within ATIGA. Fortunately, the $4^{\text {th }}$ AFTA Council in 1993 had requested Member Countries to submit information on measures that may

Community: Progress, Challenges, and Prospects. ADBI Working Paper Series No. 440, p. 14

21 The Asian Foundation. (2014). Regional Economic Cooperation Forum: Making AEC work for SMEs. Bangkok, Thailand: The Asian Foundation, p. 5

22 ASEAN.ATIGA, Art. 2(1)(k)

23 ASEAN.ATIGA, Art. 40(1)

24 ASEAN.ATIGA, Art. 41

25 ASEAN.ATIGA, Art. 2(1)(n) 
constitute barriers to trade. ${ }^{26}$ Based on the information submitted by Member States, AFTA Council could identify at least 2 major NTB, those are:

a) Customs surcharges: Customs surcharges and technical measures were initially identified as major NTBs affecting intra-ASEAN trade. A customs surcharge, also called surtax or additional duty, is an ad hoc trade policy instrument to raise fiscal revenue or to protect domestic industry. ${ }^{27}$

b) Technical measures: Technical measures are those measures referring to product characteristics such as quality, safety or dimensions, including the applicable administrative provisions, terminology, symbols, testing, and test methods, packaging, marking and labelling requirements as they apply to a product. $^{28}$

As previously explained, forms of NTB are evolved from the time being, making above list insufficient in preparing the Small Medium Enterprise (SME) from predicting any NTB it might face when exporting goods to other ASEAN countries. One of key solutions to resolve this was presented during Regional Economic Cooperation Forum in Bangkok on March 2014. The proposed solution is that there should be a fully

26 Learning ASEAN.(2014) ASEAN Free Trade Area (AFTA Council), Learning ASEAN Website. Available from: http://learning.asean.org/news/ asean-free-trade-area-afta-council-34947.html. [Accessed 25/03/2015].

27 ASEAN. Elimination of Other Non-Tariff Barriers, ASEAN Website. Available from: http:// www.asean.org/communities/asean-economiccommunity/item/elimination-of-other-non-tariffbarriers, [Accessed 25/03/2015]

28 ASEAN Website, Op. Cit. operational and accessible database which is able to regularly identify any non-tariff barriers within ASEAN in order to assist small medium enterprises (SME) to well adapted in the upcoming AEC. ${ }^{29}$

ASEAN, during the time ATIGA was drafted, tried to resolve the following issue by proposing the creation of ASEAN Trade Repository (ATR), a record containing trade and customs laws and procedures of all Member States in which on separate obligation each of ASEAN Member States are obliged to establish their own national repository and made accessible to the public through the internet. ${ }^{30}$ The ATR, among others will be expected to carry information on tariff nomenclature; preferential tariffs offered under the ATIGA; Rules of Origin; NTB measures; national trade and customs laws and rules; documentary requirements; and list of authorised traders of Member States. ${ }^{31}$

Once established and fully functioning, the ATR and the information contained therein will be accessible through the internet to economic operators like exporters, importers, traders, as well as government agencies and the interested public and researchers. ${ }^{32} \mathrm{It}$ is the ASEAN Secretariat which shall maintain and update the ATR based on the notifications submitted by Member States. ${ }^{33}$ Currently, ASEAN is developing the design and mechanism of the $\mathrm{ATR}^{34}$ while relying any dissemination of trading information on the

\footnotetext{
29 See The Asian Foundation. (2014). Op. Cit., p. 13

ASEAN.ATIGA, Art. 13(1)

ASEAN.ATIGA, Art. 13(2)

ASEAN, ATIGA, Art. 13(1)

ASEAN, ATIGA, Art. 13(3)

4 ASEAN. Trade Facilitation in ASEAN. AEC Report 2015, p. 2
} 
respective national repositories maintained by the Member States.

\section{Dispute Settlement}

With the existence of the exception clauses, any interstate disputes arising in intraASEAN trades could be well expected after AEC is established. ATIGA tries to anticipate the issue by referring any differences on its interpretation to be settled under the ASEAN Protocol on Enhanced Dispute Settlement Mechanism [ASEAN-PEDSM]. ${ }^{35}$ ASEANPEDSM, as the name suggests, is an ASEAN Protocol that listed several means of resolution, such as the Forum of Consultation ${ }^{36}$, Establishment of Panel $^{37}$ and Initiation of Appellate Body to review the Panel's report and legal interpretations developed by the Panel. ${ }^{38}$ This Mechanism is applied on disputes relating to all subsequent economic commitments in ASEAN as well as retroactively to earlier key economic agreements.

At the heart of this Protocol is a mandatory dispute settlement process involving panels and an appellate body to assess disputes that cannot be settled through good offices, mediation or conciliation. Based on the findings of the panel or appellate body, a member state may be requested to take measures to bring itself into conformity with an ASEAN economic agreement.

This protocol is problematic in twofold. First, the whole processes are considered costly and time consuming. The

\footnotetext{
35 ASEAN, ATIGA, Art. Art. 89

36 See ASEAN. ASEAN Protocol on Enhanced Dispute Settlement Mechanism (ASEAN-PEDSM). 2004, Art. 3

37 See ASEAN. ASEAN-PEDSM, Art. 5

38 See ASEAN. ASEAN-PEDSM, Art. 12
}

following Table 1 explaines process and duration in ASEAN-PEDSM.

Table 1. ASEAN-PEDSM Process, Action and Timeline ${ }^{39}$

\begin{tabular}{ll}
\hline Duration & \multicolumn{1}{c}{ Process and Action } \\
\hline 60 Days & $\begin{array}{l}\text { Consultation } \\
\text { SEOM establishes panel and disputants } \\
\text { appoint panelist }\end{array}$ \\
60-70 & $\begin{array}{l}\text { Panel assessment and reports to be } \\
\text { submitted to the SEOM }\end{array}$ \\
30 Days & $\begin{array}{l}\text { The SEOM to decide on the adoption of } \\
\text { the panel's report }\end{array}$ \\
60-90 & $\begin{array}{l}\text { The EDSM Appellate Body - Appeal } \\
\text { proceeding and submission of report to the }\end{array}$ \\
Days & $\begin{array}{l}\text { SEOM } \\
\text { The Days }\end{array}$ \\
& $\begin{array}{l}\text { of the Appellate Body's report } \\
\text { Compliance by disputing parties to the } \\
\text { report's findings and recommendation } \\
\text { (may decide on a longer period) }\end{array}$ \\
\hline
\end{tabular}

From table above, we can infer that to merely request for ATIGA interpretation, one had to undergo lengthy road of dispute settlement phases.

Secondly or as result from the first problem, unlike the other international dispute systems which have proven their track record in resolving disputes on the basis of international law, ${ }^{40}$ ASEAN-PEDSM has lack of record resolving disputes between Member States and to interpret economic agreement such as ATIGA. Indeed, the Intra-ASEAN disputes exist, but the Table $2^{41}$ would allow us to conclude that Member States have strong tendencies to prefer dispute settlement outside ASEAN EDSM.

39 Michael Ewing Chow and Ranyta Yusran. (2014). If You Build It They Still Will Not Come: ASEAN Trade Dispute Settlement Mechanism. PPT Presentation. Singapore: National University of Singapore, p. 7

40 Michael Ewing Chow and Ranyta Yusran. (2014). Op.Cit, p. 16

$41 \quad$ Ibid. p. 11 
Table 2. Historic Records of Intra-ASEAN Disputes (1959 - 2013)

\begin{tabular}{llcc}
\hline \multicolumn{1}{c}{ Dispute } & \multicolumn{1}{c}{ Parties } & Period & Forum \\
\hline Temple of Preah Vihear & Cambodia v. Thailand & $2010-2013$ & ICJ \\
Thailand Cigarettes & Philippines v. Thailand & $2008-2011$ & WTO DSB \\
Land Reclamation & Malaysia v. Singapore & 2003 & Ad hoc tribunal under UNCLOS \\
Pedra Branca & Malaysia v. Singapore & $2003-2008$ & ICJ \\
Sipadan-Ligitan & Indonesia v. Malaysia & $1998-2002$ & ICJ \\
Polythylene and Polypropylene & Singapore v. Malaysia & 1995 & WTO DSB \\
Temple of Preah Vihear & Cambodia v. Thailand & $1959-1962$ & ICJ \\
\hline
\end{tabular}

Nothing ASEAN could do but to modify its own dispute mechanism to meet its Member State needs. For this reason, the other regional dispute settlement in European Union (EU), namely the European Court of Justice (ECJ) can be a comparasion for ASEAN. EU tried to simplify its interpretation procedures by granting dominant role to its judicial authority, the ECJ. It give ECJ the position of the sole authority to rule on the interpretation or to assess the validity of the EU law through the optional preliminary rulings ${ }^{42}$ or litigation proceeding brought against EU governments. ${ }^{43}$ It is also called upon to act as administrative court for EU institutions $^{44}$ and to enforce monetary penalties to oblige member states to comply with the Court's rulings.

What EU achieves so far from the dominant role of ECJ is remarkable, Up to May 2009, the Court of Justice had given 7968 verdicts and The Court of First Instance has added 2354. In total, the politically decided Acquis of Community law has been supplemented by 10,322 Court of Justice verdicts. ${ }^{45}$ In deciding on these verdicts, the

42 European Union (EU).Treaty on the Functioning of European Union (TFEU). 2007, Art 19(3)

43 EU. TFEU. Art. 258; See also EU. TFEU. Art. 19(3)

44 EU. TFEU. Art. 268

45 EU ABC, Court of Justice/EU Court, EU
Court has been assisted by 3326 preliminary statements from its advocates-general. These normally conform to what the Court later decides, but not necessarily so. ${ }^{46}$

Adopting TFEU ways to give certain institution mandate such as the 'optional' preliminary rulings would not constitute breach on ASEAN's 'non-interference' value.Firstly, ATIGA rules on the free flow of goods already embedded on national laws the moment ASEAN States have ratified the Treaty. Secondly, procedure such as 'preliminary rulings' would not deprive local courts from its judiciary powers, since Appellate Body under ASEAN-PEDSM could only provide suggestive interpretations where the local courts still retain its final says on any disputed caused by ATIGA. If there is any implication, it would be to prevent local courts from interpreting ATIGA outside its commonly agreed terms, contexts or even against the intentions of the drafters.

\section{ASEAN on Protection of Intellectual Properties}

As companies shift or expand operations for the AEC, a major consideration for many will be the protection and the development

ABC Website, Available from: http://en.euabc. com/?word id=242. [Accessed 06/04/2015]

46 Ibid 
of Intellectual Property (IP). Many have concerned over the IP protection in ASEAN, where the concept of IP only to receives cold welcome by some authorities in ASEAN's developing states and are still evolving in many of the more developed nations. ${ }^{47}$

Investors and international traders are likely to focus on countries where IP is adequately protected. Singapore for example, has concentrated on positioning itself as an IP hub in Asia for a number of years. Significant thought has gone into development of laws and regulations for the protection of IP as well as incentives for IP and Research and Development activities. Singapore's strengths in this area bring a distinct advantage, and, as pointed out in the Blueprint, are a major determinant of external competitiveness. ${ }^{48}$

The upcoming AEC has recognized the need for a cohesive set of IP laws in the region, and has sought to craft an approach to IP that takes into account the diverse needs and varying levels of capacity of its member states. ${ }^{49}$ Instead of trying to formulate a single set of laws and designing a harmonized regional system in IP, ASEAN decided to create the ASEAN Intellectual Property Rights (IPR) Action Plan 2011-2015, a higher level of cooperation by undertaking programmers and activities together with Member States, by strengthening linkages with each other to improve their capacity,

47 See KPMG International.(2013). ASEAN Tax Guide. Switzerland: KPMG Asia Pacific Tax Centre, p. 6

48 Ibid., p. 7

49 ASEAN.ASEAN Intellectual Property Rights Action Plan 2011-2015. Section 1.0, p. 1. Available from: http://www.asean.org/archive/documents/ ASEAN\%20IPR\%20Action\%20Plan\%2020112015.pdf. [Accessed 29/06/2015] and participating in global IP structures, subject to the capacity and readiness of each Member States.

Perhaps this is the safest means to accommodate diverse IP regulations in the region, but the 2015 Article made by Marks \& Clerk - London based international firm of patent and trade mark -indicates rather slow and stagnate development among several ASEAN countries from striving to meet the global IP standards. ${ }^{50}$

a) Brunei, Cambodia and Laos have been slower to embark upon trade mark reform. For Cambodia and Laos, in the process of industrializing, and for Brunei, with its limited population, trade mark protection and enforcement are not particularly high on the respective governments' list of priorities.

b) The political turmoil in Thailand has had an adverse effect on its IP regime. Due to demonstrator's occupation in Ministry of Trade, Thailand's Department of Intellectual Property was forced to close down for about a quarter of the year, making the progress on the proposed amendments to Thailand's trade mark law has come to a standstill.

c) Indonesia also faced few major challenges on its Trade Mark reform. First1y, The Indonesian Trade Mark Office does not currently have an electronic filing system and it is facing a significant backlog of trade mark applica-

$\overline{50}$ Henry Goodwin at Taylor Vinters. (2015). Brand Protection in ASEAN - A Practical View. Available from: http://www.marks-clerk.com/Home/ Knowledge-News/Articles/Brand-protection-inASEAN.aspx\#.VZCtUUZxySo. [Accessed 29/06/ 2015] 
tions. Secondly, some of the practices and regulations of the Indonesian trade mark office are outdated and extremely unfriendly to businesses.

d) Lastly, the National Office of Intellectual Property in Viet Nam has a huge backlog of pending applications that continues to mount with the increase in foreign direct investment and more companies bringing their brands into Vietnam.

While other Member States have shown positive progress on their IP reforms, this finding would imply that the IPR Action Plan had not meeting up its end goals equally to all Member States. To make matter worse, due to non-interference principle, ASEAN also are refrained from directly handling these national IP matters. In conclusion, ASEAN might need more than 2011-2015 timeline for its IPR Action Plan to effectively works.

\section{CONCLUSION}

With the remaining tariffs on sensitive list and highly sensitive list soon to be eliminated, ASEAN Member States should be constantly reminded on the economic impact of single market towards the sale of agricultural products, in particular for poor farmers and urban workers. Single market should be on the first place share the benefits of integration more equitably to all ASEAN population.

Having eliminated most of intra-ASEAN tariffs, ASEAN should shift its main priorities from tariff zeroing to eliminate NTB which remains an imminent threat for businesses involved in intra-ASEAN trade. By nature, many NTBs in global trade are not self-made rather being strongly linked with government protectionist policies. Therefore, there will be strong need on the future to identify and address the legislative and regulatory limitations that impede the implementation of intra-ASEAN commitments. While most of national repositories are now accessible to assist the identification of trade barriers, recent delay in operating ATR would risk ruining the starting impression of AEC among ASEAN traders and investors.

Being perceived as costly and time consuming, the ASEAN-PEDSM had never been entrusted in resolving trade dispute or even ASEAN related disputes in general. Learning from EU judiciary body, the ECJ, we did understand that the 'simplicity' on due process is what makes the productiveness in ECJ is appealing for its Member States. In conclusion, by giving the shorter course to reach ASEAN Appellate Body, it would indirectly regain the trusts of Member States to resolve their disputes to ASEANPEDSM.

Finally, ASEAN exporters and importers should fond that by the start of AEC, they could not expect most of ASEAN countries to provide the same level of IP protection as Singapore or other IP hubs in the globe do. Reiterating what Marks \& Clerks has suggested, ASEAN based businesses should consider protecting their brands in each ASEAN country which is relevant to them commercially, and the measures being brought in under the AEC should strengthen cross-border protection of innovative ideas and products in the years to come. ${ }^{51}$

$\overline{51}$ Henry Goodwin at Taylor Vinters. (2015). Op. Cit. 


\section{BIBLIOGRAPHY}

Books:

Asian Development Bank. (2014). ASEAN Community 2015: Managing integration for better jobs and shared prosperity. Thailand: International Labour Organization and Asian Development Bank.

Michael G. Plummer and Erik Jones. (2006). International Economic Integration and Asia: Advanced Research in Asian Economic Studies. Vol. 3. Singapore: World Scientific.

Rudolf Dolzer. Rudolf Bernhardt and Rudolf L. Bindschedler. (1984). Encyclopedia of Public International Law. Vol. 7. Amsterdam, the Netherlands: NorthHolland

Journal and Articles:

Ashish Kumar Singhal. (2012). Doctrinal and Socio-Legal Methods of Research: Merits and Demerits. Educational Research Journal. Vol. 2(7). July 2012. Available from: http://www.resjournals.com/ERJ. [Accessed 17/11/2014]

KPMG International. (2013). ASEAN Tax Guide. Switzerland: KPMG Asia Pacific Tax Centre

Siow Yue Chia. (2013). The ASEAN Economic Community: Progress, Challenges, and Prospects. ADBI Working Paper Series No. 440

International Organization Documents:

ASEAN. (2014). Thinking Globally, Prospering Regionally: ASEAN Economic Community 2015. Jakarta, Indonesia: ASEAN

ASEAN. (2014). Thinking Globally, Prospering Regionally: ASEAN Economic Community 2015. Jakarta, Indonesia: ASEAN

ASEAN. (2015). Trade Facilitation in ASEAN. AEC Report 2015

Asian Development Bank. (2014).ASEAN Community 2015: Managing integration for better jobs and shared prosperity. Thailand: International Labour
Organization and Asian Development Bank.

Organization for Economic Co-operation and Development. (2005). Regional Integration in the Asia Pacific: Issues and Prospects. Paris: Organization for Economic Co-operation and Development.

The Asian Foundation. (2014). Regional Economic Cooperation Forum: Making AEC work for SMEs. Bangkok, Thailand: The Asian Foundation

Declarations, International Agreements and Treaties:

ASEAN. Agreement on the Common Effective Preferential Tariff Scheme for the ASEAN Free Trade Area.1992

ASEAN. ASEAN Economic Community Blueprint. 2007

ASEAN. ASEAN Intellectual Property Rights Action Plan 2011 - 2015. 2011

ASEAN. ASEAN Protocol on Enhanced Dispute Settlement Mechanism. 2004

ASEAN. ASEAN Trade in Goods Agreement. 2010

European Union. Treaty on the Functioning of European Union. 2007

Other Sources:

ASEAN. Elimination of Other Non-Tariff Barriers, ASEAN Website.Available from: http://www.asean.org/communities/asean-economic-community/item/ elimination-of-other-non-tariff-barriers, [Accessed 25/03/2015]

Asian Economic Institute. (2015). Trade Organizations: ASEAN. Available from: http://www.asiaecon.org/trade_relations/get_to_item/4. [Accessed 27 June 2015]

EU ABC, Court of Justice / EU Court, EU ABC Website, Available from: http:// en.euabc.com/?word_id=242.[Accessed 06/04/2015]

Henry Goodwin at Taylor Vinters. (2015). Brand Protection in ASEAN - A Practical View. Available from: http://www. marks-clerk.com/Home/Knowledge- 
News/Articles/Brand-protection-inASEAN.aspx\#.VZCtUUZxySo. [Accessed 29/06/2015].

Learning ASEAN.(2014). ASEANFree Trade Area (AFTA Council). Available from: http://learning.asean.org/news/aseanfree-trade-area-afta-council-34947. html. [Accessed 25/03/2015].

Michael Ewing Chow and Ranyta Yusran. (2014). If You Build It They still will not Come: ASEAN Trade Dispute Settlement Mechanism. Power Point Presentation. Singapore: National University of Singapore. 